\title{
Men's Perspective about the Care and Services of Primary Health Care
}

\begin{abstract}
Ellen Kelly de Oliveira Paula ${ }^{1}$, Rosely Leyliane dos Santos ${ }^{2}$, Edilma Gomes Rocha Cavalcante ${ }^{3}$, Natalia Bastos Ferreira4, Roberta Peixoto Vieira ${ }^{5}$, Edeiza Ataliba Bastos ${ }^{6}$, Alex Porfírio dos Santos7, Poliana Sousa Amorim ${ }^{8}$, Maria de Fátima Antero Sousa Machado9
\end{abstract}

\section{Abstract}

Introduction: Men health in recent years has been excelling in the discussions about the public health policies. This fact has occurred due to increasing rates of male mortality and morbidity associated with low demand for health services, especially primary health care. Objective: To analyze the perception of men about health services within primary heath care

Method: Descriptive study of qualitative approach carried out with 17 men, residents in urban area of the municipality of São Mateus, Ceará, Brazil and assisted by family health teams. The data were collected in October 2015 through semi-structured interviews and treated according to the technique of thematic content analysis developed by Minayo.

Results: Three themes have been identified: evaluation of care received the Perception the male population: bad, awful, restricted or non-existent and a minority considered satisfactory; Difficulties perceived about the services and facilities provided to men - assignment difficulty, use of unified health system (SUS) card, functioning hours, care discontinuity (lack of medicines, examinations) long queues and waiting time. Were facilities: Organization, customer service and timely appointments; Suggestions for improving the quality of care the health of men were: specific schedule to meet the man, performing educational actions, encourage them to look for the service, with a focus on prevention, self-care and health promotion. In addition to the need to improve the infrastructure, organization, moreover, very good breakfast choice and qualify health professionals.
1 Enfermeira pela Universidade Reginal do Cariri, URCA, Brazil.

2 Mestranda em Enfermagem pelo curso de mestrado acadêmico da URCA. Docente. Membro do Grupo de Pesquisa em Saúde Coletiva (GRUPESCURCA).

3 Docente URCA. Doutora em Ciência. Membro do Grupo de Pesquisa em Saúde Coletiva (GRUPESC-URCA); Universidade Reginal do Cariri. URCA, Brazil.

4 Mestranda em Ciências da Saúde pela FMABC. Universidade Reginal do Cariri, URCA, Brazil.

5 Docente. Universidade Reginal do Cariri, URCA, Brazil. Mestre em Saúde da Criança e do Adolescente.

6 Docente URCA. Mestre em Em Ensino na Saúde pela Universidade Estadual do Ceará, Brazil.

7 Enfermeiro Assistencial. Ceará, Brazil.

8 Acadêmica de enfermagem da Universidade Reginal do Cariri, URCA, Brazil.

9 Docente. Universidade Reginal do Cariri, URCA, Brazil. Líder do Grupo de Pesquisa em Saúde Coletiva (GRUPESCURCA).

\section{Contact information:}

\section{Italla Maria Pinheiro Bezerra.}

Address: EMESCAM. Escola Superior de Ciências da Santa Casa de Misericórida de Vitória. Av. N. S. da Penha, 2190, Santa Luiza, Vitória, ES - 29045-402.

Tel: (27) 3334-3537

Е italla.bezerra@emescam.br 
Final thoughts: the perception of men on primary health care predominated the negative judgment on the services and care provided concerning the restructuring needs of the services, qualification of health professionals and program availabilities/actions specific to men's health and engagement in health promotion and prevention through health education.

\section{Keywords}

Man Health; Access to Health

Services; Completeness in

Health; Primary Health Care.

\section{Introduction}

Human health in recent years has been excelling in the discussions about the public health policies of men. According 2010 epidemiological data, this fact has occurred due to increasing rates of male mortality and morbidity associated with low demand for health services, particularly primary health care [1].

The Basic Attention in Health (BAH) is the first level of attention and is configured as a strategy for the organization, referred to as the gateway to health services [2]. Accordingly, it was proposed by the Ministry of Health and Family Health Strategy (FHS), whose ideals are based on completeness, decentralization of social services and capillarity.

However, this completeness presents challenges, especially in the case of access difficulties presented by the male population in the FHS. It is known that the perception of men about the health services is heavily influenced by stigmas associated with frailty, where the old man believes that preventive actions are only female activities [3, 4, 5].

This stigma is associated with the organization of the system that historically has been drawn from the development of the health care of women, children and elderly. Where public policy for decades prioritized gravid-puerperal cycle, offering programs that have remained geared to this audience $[5,4]$.

With the launch of the National Policy of Integral Attention to Health (NPIAH/PNAISH), by the Brazilian Federal Government in 2009, it was found the possibility of an extension of the male access to health services. The policy aims to improve the health conditions of the Brazilian male population, reducing morbidity and mortality, through tackling the risk factors and by ensuring the accessibility to the actions and the integral health assistance services. Currently this policy works with five priorities: access and host; paternity and care; diseases prevalent in the male population; prevention of violence and accidents; and sexual and reproductive health [6].

In this context, some questions emerged: what factors influence the man to seek the attendance in a basic health unit for promotion and prevention health services? What are the perspectives of man on this service?

The personal interest in studying this issue arose through the observation of flow in primary care units, where it was found that the male population is the group that has not attended a lot in health services.

The relevance of the research is expressed by allowing a portrait of reality, trying to identify strategies for inclusion in health services, as well as their awareness of searching it. It is hoped that the study provokes reflections about human health by raising questions that will assist in the integral care to male health in the regional scenario.

Therefore, the objective of this study was to analyze the perception of the man on health services within the primary health care.

\section{Method}

A descriptive-exploratory study with a qualitative approach, developed in the city of São Mateus, Ceará, 
Brazil. The participants were chosen randomly, the data were collected in three FHS in the urban area, in October 2015, using as criteria for inclusion: men linked to the study's FHS and aged 25 to 59 years old, the age group that PNAISH stands out. Men who were unfit to verbalize were excluded.

The interviews were conducted after the contact and awareness of the FHS nurses, in which it was provided a reserved place of the unit for the interviews. Seeking the service, men were invited to participate in the research. Composed this study 17 men. For the data collection was conducted a semi-structured interview script, consisting of guiding questions on the topic: perception of how services are offered by basic care and what are the facilities and/or difficulties in accessing these services. To ensure anonymity, the participants were identified with the letter " $\mathrm{P}$ " and the corresponding number, example: P1, P2, ..., P17.

Data were analyzed according to the thematic analysis of content proposed by Minayo, focused on discover the core meanings that compose communication whose presence or frequency mean something to the targeted analytical objective7. Three categories were proposed: evaluative perception of care received by the male population; Difficulties and facilities perceived about the services provided to men; Suggestions for improving the quality of men's health care.

The search followed the recommendations of Resolution 466/12 of the National Council of health of the Ministry of Health8, with approval of the Research Ethics Committee of the Regional University of Cariri (URCA/ZIP CODE): 1.256.678/15.

\section{Results}

\section{Characterization of the participants}

Study participants were 17 men aged between 25 and 59 years (average 41 years). As for the level of education, 5 (28\%) participants had complete high school, 4 (24\%) complete higher education, 3 (18\%) complete primary education, 3 (18\%) illiterate, $1(6 \%)$ incomplete higher education and 1 (6\%) incomplete secondary education.

In relation to marital status, ten were married (58.82\%) and with household income of two minimum wages (35.29\%), based on the minimum wage in force at the time of $R \$ 788.00$.

Among the occupations declared by informants in this study, the most outstanding were the teacher and farmer representing the same percentage of $18 \%$.

\section{Thematic Categories}

\section{Evaluative perception of the care received by the male population}

Asked about the assessment of health services provided to men, the participants presented difficulty in sorting this attendance. Most saw service as "regular" because it lacked to meet other demands for it to be classified as a "full service", although it did not specify what they might be. They signaled that the service was "restricted or limited", because it boiled down to the medical attendance, with difficulty in accessing specialized services outpatient when were referenced. It can be seen in the following:

Regular, because the services that are there we can get when we need to, but still a lot has to be done to be considered a complete service.

[...] the only thing that's there for the man is a medical consultation, that neither is specialized, only serves to escalate to an expert and that most of the time we can't go.

Negative ratings were also identified and in general the participants evaluated the services as "bad", "awful", and even "non-existent". These were associated with the precarious conditions of the health 
service and, especially, by not being decisive in meeting the health problems and needs of the male population.

Too precarious [policies of health services].

I think that leaves something to be desired [the offer of health service].

I don't sort, because it doesn't exist. Is insufficient, without resolution, bureaucratized to the extreme, inaccessible, doesn't actually exist to the male population.

Below are testimonials from men who considered the quality of the service provided "satisfactory" and were closely related to the completeness and the reception to enhance the Organization to ensure access to services and the good service.

I think it's good, because it looked better now to schedule the medical consultation, so it doesn't have an uproar of people, have come on the right day.

It's good, I was well attended [...].

\section{Difficulties and facilities perceived about access to services available to men}

The participants revealed reasons that influenced their low frequency and/or their absence to health services. Were listed difficulties in getting the medical consultation and the hours of operation that match their labor activities. They also pointed to little flexibility in companies in releasing them to health care.

Is a bigger difficulty leaving the job to go to try to get an appointment, a service.
What makes it difficult is because of my job, as I work at the same time it is opened, there is a little difficulty.

There is a difficulty because the clinic has only attendance during the day and lately, sometimes I needed was at night, so I always try to hospital services. The work also hampers because sometimes it's hard to get out.

As for the difficulties which weaken attendance, were reported the discontinuity of care due to lack of medicines; unavailability of examinations or vacancies for medical consultations, generating long standby time and the need for inputs.

There's no medicine, you query brings up a recipe and have to buy the medicine because it does not have.

[...] the case of exam schedule is very difficult because it's a lot of people that spend a lot of time there, going on until 6 months waiting.

Sometimes we give a wasted journey, it's not every day you have. This review I'll show was already more than a year it was for me to have done and I could only now.

The men mentioned yet the discontent and dissatisfaction with public health, given the precariousness of public services, in particular the FHS, which fails to meet their demands. In addition to the difficulty with the SUS card use, which should facilitate the access of care, users face the bureaucracy of routing and scheduling system, the long medical consultations and frequent returns to the health unit. 
These issues are linked to socio-economic difficulties of patients who do not have access to public transportation.

[...] queue handle it, take line to here [...] It's more difficult for the poor who do not have a carriage [...] there takes a password, a process [...]

The bureaucracy is the main difficulty [...] the unit doesn't give a proper resolution, why do you need medication that usually don't have, need an expert evaluation with urgency, which usuaIly is only going to happen 3 or 4 months later. [...] even invented a markup or central register or whatever, where the citizen can only care if you have this card, and the SUS card good for nothing?

In contrast to previous reports, five participants reported timely care related facilities whenever sought the health unit, the organization of care and scheduling through appointments. Only one participant pointed out how easily the geographical access and transportation that allowed to seek assistance whenever needed to get around the health unit.

For me it's easy because I do not have what to do, I have a car when I want I go there and come back here. For me there's no difficulty.

I think easy, whenever I try I am answered.

It's easy, it's easy, it's very easy. Why has an organization, a better service.

I was able to easily make an appointment.

P05.

\section{Suggestions for improving the quality of care for men's health}

The suggestions listed by participants were activities that mobilize and ensure the participation of men in care with their health through programs or through campaigns such as the Blue November and provision of more tests to prevent sexually transmitted infections. Pointed out the necessity of drawing up a timeline that specify a day to meet the demand. In addition to the need for health education initiatives attractive to the target audience (young) using videos and/or form groups to encourage the promotion and the prevention of infectious diseases.

Was to have the right day for a consultation; in the case of the November blue, an interview, a campaign; bring them, show videos. Because the woman, such a day has prevention: you want to mark. And the man? Why can't have?

There has to be more government programs, encouraging the municipality, too, in the same way it has for the woman. [...] If they did more campaigns, encourage the man to participate, would be much better and I believe it would prevent many diseases.

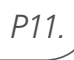

Promote events, groups, lectures, open more tests for men, such as prostate and tests to detect STDS 's and also campaigns for adolescents.

About the management aspect, the subject consider that a responsible management should offer full quality assistance, ensure the infrastructure of the health services, reduce bureaucracy, facilitate access and empower healthcare professionals to provide quality care.

[...], we had good doctors, had expert, had air conditioning.

P09. 
All this is for interference, [...] lack of management, optimize the assistance, [...] reduce bureaucracy, easy access, improve employees with continuing education. Because sometimes we encounter with professionals totally unprepared for the job.

P15.

Other suggestions for improving the quality of health services were related to more investment in healthcare, better prevention programs and actions to meet the demands and needs of human health. In addition to the need of reducing the bureaucratization of the services that allow the resolution and speed.

More investments in health care, a more qualified and less bureaucratic for what the problems are resolved faster.

More health programs, according to age and need.

Have more resources [...]. Oh you analyze... Why have so many people dying? Is it because they're not preventing? Or is it because they're expecting too much a system so bureaucratic and ineffective?

P01.

\section{Discussion}

The results show that most of the men in the study was composed of young adults and adults, with full high school, married, with household income of more than one minimum wage and with teacher occupation or farmer. The assessment of care provided to men in the FHS, was considered negative (bad, awful, restricted/limited and non-existent) for failing to meet their demands and needs; While a minority considered as satisfactory.

In this context, recognizing and valuing this subjective dimension of users, requires sensitivity of managers and health professionals in the quest to qualify the services provided and modify health welfare practices.

In this critical assessment, the men pointed precisely the limitations from the health service. These difficulties were linked to precarious conditions of service, lack of efficaciousness, restricted calls to medical consultations and the difficulties of the reference and counterreference systems to the specialist services.

The diversity of aspects evaluated as negative, from the identification of the need for more investment to the guarantee of universal access, equitable and fair to the reference and fragility of access presented as difficulties the delay in attendance, the long break in the schedule of exams and availability and lack of resolution. These obstacles are the reasons that make men move away from health services $[9,10]$ and serve as parameters that express the satisfaction and dissatisfaction on the part of men in relation to available attendance [11].

Recommendations for quality service including prevention, promotion and rehabilitation of health walk in the direction of the offer that meets the male specificities. Being able to relate to clarification meetings, campaigns, expert assistance, mainly urology [11], in order to meet fully this portion of the population.

Were highlighted in the present study, complaints concerning the lack of specialized care, timelines and more programs to meet the specific needs. As prerogative was put that the service has an established demand to attend women. This awareness and perception of the SUS rights allowed the comparison between expectations and what happens in reality of the basic attention services practices. In fact, there are situations in which men feel excluded or does not belong to those spaces, because they are historically and typically frequented by women [3]. It reinforces the differences between genders regarding the assistance as was identified in a study of four Brazilian States [11]. 
Still, on the difficulty on health care, it is worth noting that much of the male group of this study was inserted in the labor market. In this sense, the hours of operation of health services do not meet the demands of the group, discouraging them with regard to access to services, for fear of being penalized if leaving the employment activities and of its commitments as were also identified in the States of Pernambuco, Rio de Janeiro, Rio Grande do Norte and São Paulo [11, 12, 13].

As a result of this situation, it becomes vulnerable to the gateway of health services of the basic attention, leading the quest for health services assistance of higher complexity, which can have an impact on late discovery of diagnostics, which is a factor in this incident population group [13]. It is emphasized the need for further discussion on the accessibility of men to health services and the need to counter strategies that enable the extension of the opening hours of the health units, such as the deployment of PNAISH perspective, to bring significant changes in increased assistance as noted in health services the States of Acre, Goiânia, Pernambuco, Rio de Janeiro and Santa Catarina $[12,14]$.

As for the service, men realize that the long queues for consultation, exams, referrals, in addition to the lack of health professionals, the lack of medicine and/or other resources are responsible for poor quality of care. The men focused that this service should be fast and punctual, so prioritize urgent and emergency services also felt in other primary health care services in the city of Recife, Pernambuco, Brazil [15].

However, in some FHS men showed as health service facilities the organization, the attendance and appointment schedule. The service is considered satisfactory when using the principles of humanization, inclusion and respect in warning users [11]. Because these elements provide a differentiated and qualified service to meet the prospect of attention to men.
The search for satisfaction is docked for completeness, in a perspective that considers the health needs of the population. The professional-userservice link are features of positive assistance that accompanies the client across the system, since the gateway up to the secondary and tertiary services. In this way, the flaws and difficulties in the host and in the formation of ties eventually disqualify healthcare [16].

In the present study, the suggestions aimed at improving the quality of health care of men concerning the need of meeting this demand with specific timelines and more programs. In addition to the inclusion of educational activities that encourage self-care and demand of services focused on prevention and health promotion. Was seconded by users the need for prioritization of actions based on procedures and examinations, but it has also been reported to lack of prevention and health promotion, and those few aspects developed by health services.

Considering these suggestions, the valuation of its specificity, in particular, requires a planned attention that can attract the male audience to unity, identifying their problems and responding to their needs of health [17].

Listening to suggestions and ideas proposed by the users in relation to the improvement in quality of care should be reviewed, so that makes it possible to establish a way to adequate the services to the real health needs of this audience, enabling the overcoming of curative assistance.

Another suggestion proposed by participants of this study was on the infrastructure of the units and the management of health services relating to the organization, moreover, very good breakfast choice and qualification of health professionals.

In fact, it is noted that there is a disarticulation of the structure and organization of the health system or extensive bureaucratization that can be the genesis of (in)visibility of this population segment in the health service. It is fostered a discussion on the 
service and the lack of provision of quality services, as well as the reorganization on attention and in structuring the system [18].

One can see that the way healthcare is provided to this audience seems to be fragile in the face of their duties, being that want punctual factor for the development of PNASH as a tool for understanding the male singular reality, seeking to strengthen the binding of this public health services [1]. For this to become possible and reach the objectives pursued by the policy, it is necessary a reorientation of the vision of how the professionals see health practices. Thus, this redirect depends on both the implementation of the actions from the perspective of health promotion, such as greater involvement of management, in order to ensure material and human resources capable of supplying the demands laid down [19].

For the health of the basic attention practices are effective and efficient in their service, it is necessary that these practices are built from the perception and expansion of attention to men's health16. For that, resources, investments, programs, agility, qualification, efficiency are needed; which are also recommendations proposed by users to remedy the problems of public service. Resonates the need for a network of responsible attention, through the initiative, and joint mobilization of governmental and non-governmental sectors of the population in general [13]. It may turn into a bureaucratized system less, with less waiting in queues.

Based on all the suggestions exposed, we can say that men need more actions directed to their particularities, where the strengthening of public policies geared to this audience is essential in the production of specific care to their singularities, whereas bio functional surfaces and socio-cultural aspects [17].

Research should be implemented to give visibility to situations like these. However, although scientific production has been increasing in Brazil, significantly increase with the proper training of health professionals who work with research in project management $[20,21]$.

\section{Conclusions}

The results of the study made it possible to say that the basic services are not a lot frequented by men, since there are many factors that impede and generate difficulty for accessibility to the unit being explained by structural, organizational, cultural issues and by the man himself with his sense of masculinity that considers itself invulnerable.

Accordingly, when analyzing the point of view of men about their health and evaluate the weaknesses and potentialities regarded by them as determinates factors in demand for health services, we can ensure more effective measures in health provision for ensuring the individuality required in addressing the particularities of this public.

The limitations of this study refer to those pertinent to the research because it was restricted to the urban area of the city which can signal the need for expansion and replication in other scenarios.

It is suggested the importance of the discussion of the activities carried out in the basic attention services for male characteristics following the principles and guidelines of the PNAISH, which requires as a matter of fact, be established and effective. That way, they can ensure health services and have a network of comprehensive care, universal, equitable, effective and decisive.

\section{References}

1. Mendonça VS, Andrade AN. A Política Nacional de Saúde do Homem: necessidade ou ilusão? Rev. psicol. Polít. 2010; 10(20).

2. GARCIA PT. Saúde e Sociedade: Atenção Básica em Saúde. São Luiz, 2014

3. Figueiredo WS, Schraiber LB. Concepções de gênero de homens usuários e profissionais de saúde de serviços de atenção primária e os possíveis impactos na saúde da população masculina. Cienc. saude colet. 2011; 16(1):935-44. 
4. Ferraz D, Kraiczyk J. Gênero e políticas públicas de saúde construindo respostas para o enfrentamento das desigualdades no âmbito do SUS. Rev Psicol UNESP. 2010; 9 (1).

5. Gomes R, Rebello LEFS, Nascimento EF, Deslandes SF, Moreira MCN. A atenção básica à saúde do homem sob a ótica do usuário: um estudo qualitativo em três serviços do Rio de Janeiro. Ciênc. saúde coletiva. 2011; 16(11).

6. Brasil, Ministério da Saúde. Portaria n 1.944, de 27 de agosto de 2009 [Acesso em: 24 fev. 2015]. Disponível em: <http://bvsms. saude.gov.br/bvs/saudelegis/gm/2009/prt1944 2708 2009. $\underline{\mathrm{html}}>$

7. Minayo MCS. O desafio do conhecimento: Pesquisa qualitativa em saúde. 12. ed. São Paulo: Editora Hucitec; 2010.

8. Brasil, Ministério da Saúde. Secretaria de Atenção à Saúde. Conselho Nacional de Saúde. Resolução n 466 de 12 de dezembro de 2012. Brasília - DF: Ministério da Saúde, 2012.

9. Brasil, Ministério da Saúde. Secretaria de Atenção à Saúde. Departamento de Ações Programáticas Estratégicas. Política Nacional de Atenção Integral à Saúde do Homem (Princípios e Diretrizes). Brasília: Ministério da Saúde, 2008.

10. Knauth DR, Couto MT, Figueiredo WS. A visão dos profissionais sobre a presença e as demandas dos homens nos serviços de saúde: perspectivas para a análise da implantação da Política Nacional de Atenção Integral á Saúde do Homem. Ciênc. saúde coletiva. 2012; 17(10)

11. Gomes R, Schraiber LB, Couto MT, Valença OAA, Silva GSN, Figueiredo WS, et al. O atendimento à saúde de homens: estudo qualitativo em quatro estados brasileiros. Revista de Saúde Coletiva. 2011; 21(1).

12. Brito RS, Santos DLA, Maciel PSO. Olhar masculino acerca do atendimento na estratégia saúde da família. Rev. Rene. 2010; 11(4).

13. Santana EM, Lima EMM, Bulhões JLF, Monteiro EMLM, Aquino JM. A atenção à saúde do homem: ações e perspectivas dos enfermeiros. Rev. Min. Enferm. 2011; 15 (3)

14. Vieira KLD, Gomes VLO, Borba MR, Costa CFS. Atendimento da população masculina em Unidade Básica Saúde da Família: motivos para a (não) procura. Esc. Anna Nery (impr). 2013; 17(1).

15. Schraiber LB, Figueiredo WS, Gomes R, Couto MT, Pinheiro TF, Machin $R$, et al. Necessidades de saúde e masculinidades: atenção primária no cuidado aos homens. Cad. Saúde Pública. 2010; 26 (5).

16. Storino L P, Souza KV, Silva KL. Necessidades de saúde de homens na atenção básica: acolhimento e vínculo como potencializadores da integralidade. Esc Anna Nery (impr.) 2013; 17(4).
17. Delgado LB. A saúde no pronto atendimento e na atenção básica: intervenção no Município de Navegantes/SC [Dissertação]. Itajaí: Universidade do Vale do Itajaí- UVI; 2013.

18 Machado MF, Ribeiro MAT. Os discursos de homens jovens sobre o acesso aos serviços de saúde. Interface - Comunic., Saude, Educ. 2012; 16(41).

19. Bezerra HMC, Machado MFAS, Antão JYFL, Monteiro CBM, Abreu LC, Garcia TTB, et al. Community health agentes and the interface with educational actions. Int Arch Med. 2015; 8 (153): $1-10$.

20. Bezerra IMP, et al. Professional activity in the context of health education: a systematic review. J Hum Growth Dev. 24(3): 255262. DOI: dx.doi.org/10.7322/jhdg.88909

21.. Monteiro CBM, Almeida Junior AD, Wajnzstejn R. Project Management in Health and Medical Research. J Hum Growth Dev. 2014; 24(3): 239-242.DOI: dx.doi.org/10.7322/jhdg.88895

\section{Publish in International Archives of Medicine}

International Archives of Medicine is an open access journal publishing articles encompassing all aspects of medical science and clinical practice. IAM is considered a megajournal with independent sections on all areas of medicine. IAM is a really international journal with authors and board members from all around the world. The journal is widely indexed and classified Q1 in category Medicine. 